\title{
إدارة البرناميج هيئة شبه المستقلة الكندي (BSO Al-Kindy) بجامعة الإسلامية الحكومية مولانا مالك إبراهيم مالانج
}

\author{
نور إستقام الماجستير \\ nistaqam@gmail.com \\ (معلماةفى كلية التربية الجامعة الإ سلامية محمدياة بيما)
}

الملخص

أهداف هذا البحث يِعنى لوصف وظائف الإدارة، الأول: التخطيط، الثانى: التنظيم، الثالث: الحركة، والرايع: الإشراف في بر:امج هيئة شبه المستقلة الكندي (BSO al-Kindy) بجامعة الإسلامية الحكومية مولانا مالك إبراهيم مالانج. هذا البحث مهم لأن هيئة شبه المستقلة الكندي هي برنامج تحلم لغة عربية ناجحة وفازت من المسابقات في المستوى الوطنية. تستخدم هذا البحث بمدخل النوعي، أما نوع البحث هو الوصفي. الموضوع في هذا البحث هو رئلس رابطة الطلاب قي قسم تعليم اللغة العربية ورئيس هيئة شبه المستقلة الكندي. وطريقة جمع البيانات المستخدمة في هذا البحث (HMJ PBA) هي الملاحظة والمقابلة والتوثيق والتثليث. أما تقنيات التحليل البيانات يعني تخفيض البيانات وعرض ولئ البيانات والاستثتاج أو التحقق. نتائج البحث يعنى من أربحة وظيفات الإدارة في الكندي جيد جدا وفي التنفيذه مناسب مع النظريات الإدارية، يعنى: الأول: التخطيط، كل رئيس انتخاب سيعقد اجتماع برنامج العمل لتحقيق الأهداف التي تم تحديدها مسبقا. الثانى: التنظيم، موجود قسمين يعنى قسم الإتصال وقسم التدربيات حيث لكل قسم له الواجبة الخاصية. الثالث: الحركة، هي التنظيم أذشطة محددة معا، و أذشطثها هي المناظرة، الشعر، قراءة الكتب، إذشاء، خطابة، الخط، الغناء، وقراءة الأخبار العربية. الرابع: الإشراف، يتم الإشراف من قبل رئيس منظمة لملاحظة وتُعاون أعضيائها خلال الثشاط.

$$
\text { كلمات المفتاح: إدارة، البرناميج الكندي }
$$

Tujuan dari penelitian ini adalah untuk mendeskripsikan fungsi manajemen, yaitu pertama; perencanaan, kedua; pengorganisasian, ketiga; penggerakan, dan keempat; pengawasan pada program BSO Al-Kindy di UIN Malang. Penelitian ini penting karena Badan Semi Otonom Al-Kindy adalah program pembelajaran bahasa Arab yang sukses karena telah memenangkan banyak perlombaan di tingkat nasional. Penelitian ini menggunakan pendekatan kualitatif tipe kualitatif deskriptif. Subjek penelitian ini adalah ketua Himpunan Mahasiswa Jurusan Pendidikan Bahasa Arab (HMJ PBA) dan Ketua Badan Semi Otonom Al-Kindy. Metode pengumpulan data yang digunakan dalam 
penelitian ini adalah observasi, wawancara, dokumentasi dan triangulasi. Sedangkan teknik analisis data yang digunakan adalah reduksi data, penyajian data, dan penarikan kesimpulan atau verifikasi. Hasil penelitian ini adalah penerapan empat fungsi manajemen di Al-Kindy sangat baik dan sesuai dengan teori manajemen, yaitu: pertama; perencanaan, dimana pada setiap pemilihan ketua akan diadakan rapat program kerja untuk mencapai tujuan yang telah ditentukan, kedua; pengorganisasian, terbagi menjadi dua devisi yaitu devisi ittishol dan devisi tadribat dimana setiap devisi memiliki tugasnya masing-masing, ketiga; penggerakan, adalah pengorganisasian kegiatan yang telah ditentukan bersama dan kegiatannya adalah debat, membaca puisi, membaca kitab, mengarang, berpidato, kaligrafi, menyanyi, dan membaca berita berbahasa Arab, keempat; pengawasan, dilakukan oleh ketua organisasi yaitu dengan mengamati kerjasama anggotanya selama kegiatan berlangsung.

Kata Kunci: Manajemen, Program BSO Al-Kindy.

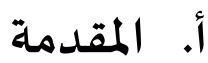

الجامعة الإسلامياة الحكومية (PTKI) هي الجامعة التي تخضع إدارنها لوزارة الدين.

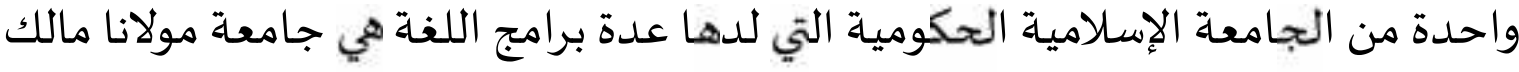

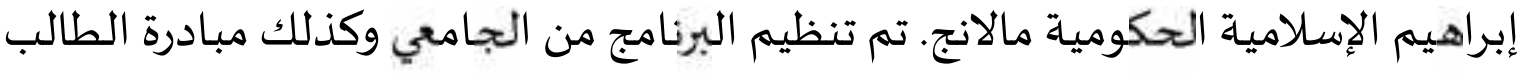

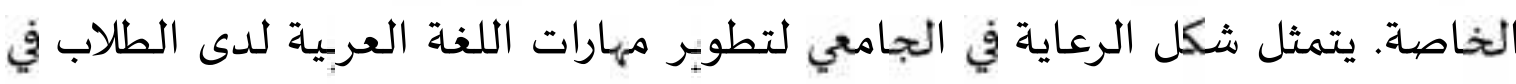

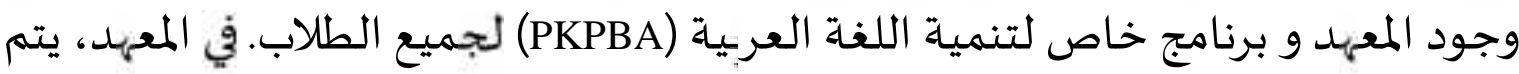
تدربب الطلاب على استخدام اللغة الأجنبية للتواصل، أي اللغة العربية واللغة الإنجليزية

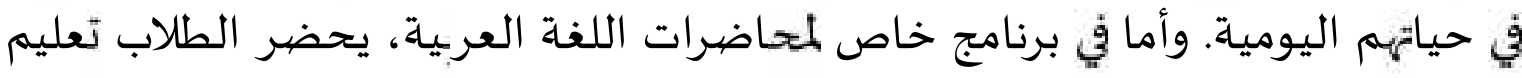

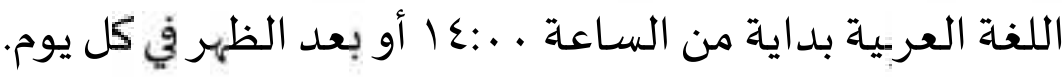

بالإضيافة إلى ذلك، أخذوا الطلاب مبادرة لتشكيل مجموعات تعلم اللغة العربية

خارج برنامج الجامعي لتطوير مهارات اللغوية. مجموعة التعلم ليست مجموعاة دراسة اليساة

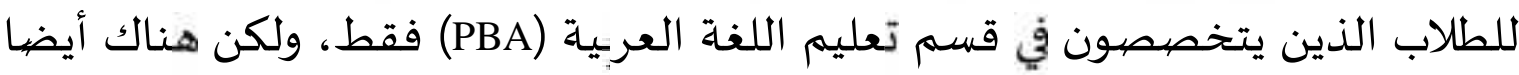
تخصصات لقسم آخر. مجموعات تعلم اللغة العربية من طلاب قسم تعليم اللغة العربية

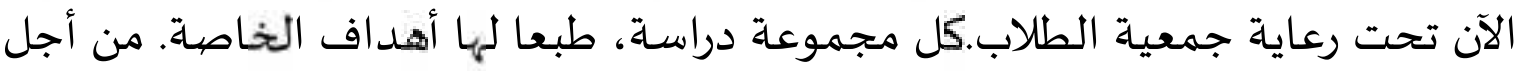
التنظيم هذا الهدف، يتطلب التنفيذ مجموعة متنوعة من الاستعداد البدني. الاستعداد

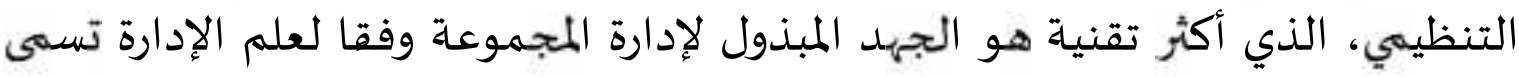

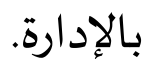


الإدارة هي عملية للتخطيط والتنظيم والحركة والإشراف الموارد لتحقيق الأهداف

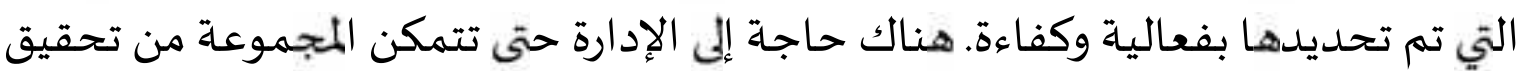

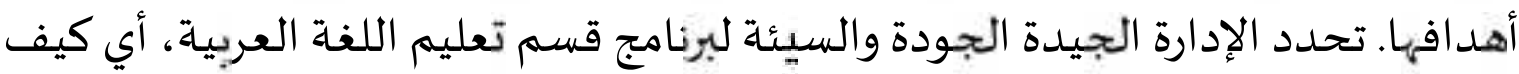

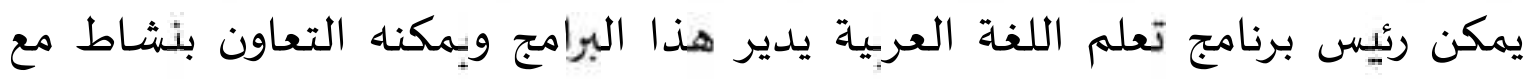
مجموعتاء. لتحقيق أهداف التربية، فإن رابطة الطلاب في تعليم اللغة العربية (HMJ PBA) يجب

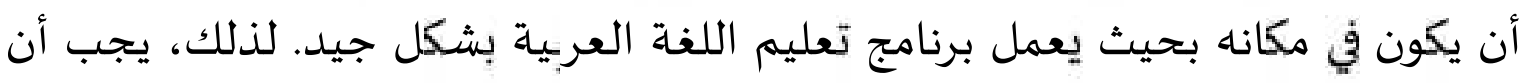

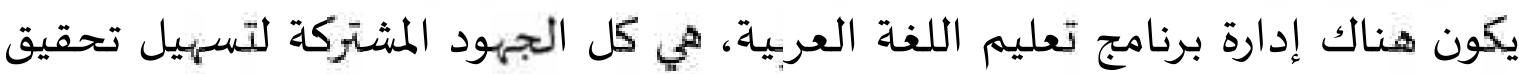

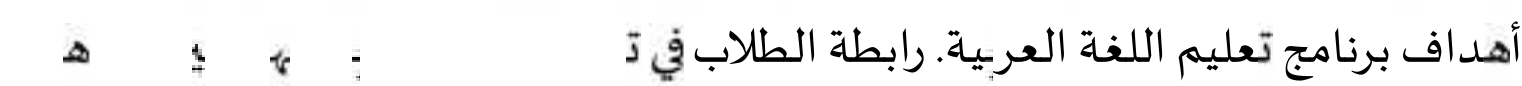

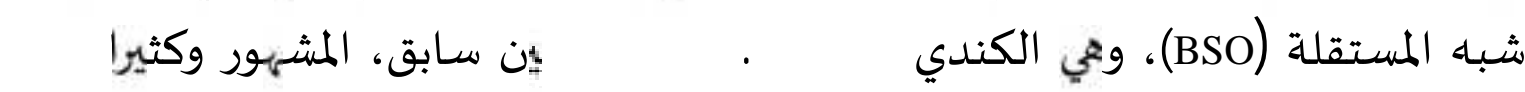
بمسابقت متنوعة، وهي الكندي.

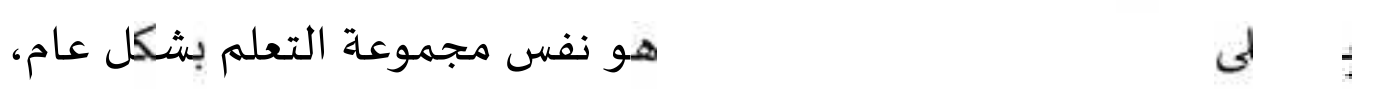
حيث يمارس الأعضاء المناقشات دون أن يقابلهم محاضر كمرشد ورفيق لأنشطههم، بالإضافة إلى عدم وجود مرافق خاصية تدعم أنشطتهم. في حين أن الحصول على الحهد الحداء

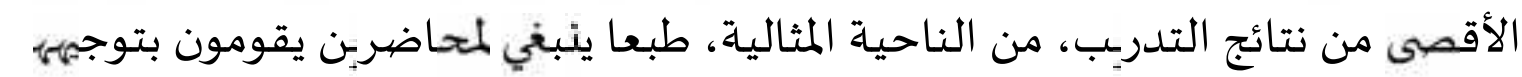
ومرافقته. هناك مشكلة أخرى وعي أنه ليس كل أعضائه يستيعون أن يتكلموا العرية

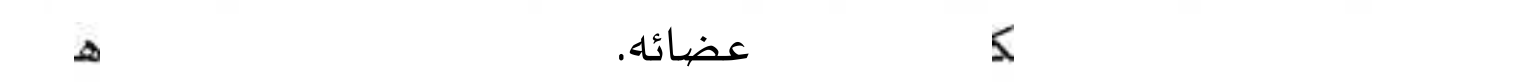
شيء مثير للاهتمام للبهث، يعني كيفية إدارة برنامج الكندي حتى يتمكنوا من الفوز في

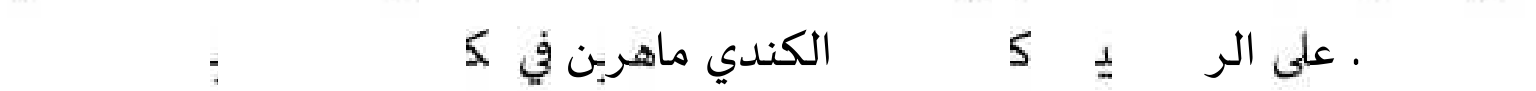

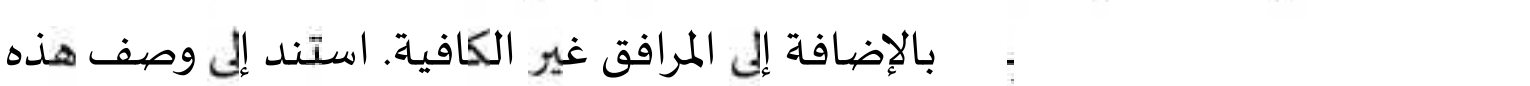

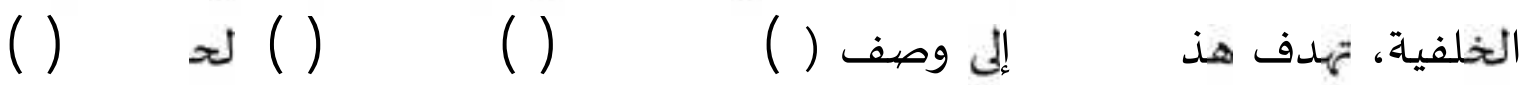
الإشرف على إدارة برنامج الكندي بجامعة مولانا مالك إبراهيم الإسلامية الحكومية مالانج. 


$$
\begin{aligned}
& \text { ب. الإطار النظري } \\
& \text { أ. الإدارة } \\
& \text { ا. تعريف الإدارة }
\end{aligned}
$$

لين الإدارة هي عملية تخطيط وتظيم وقيادة والإثرو جهود الأعضاء ولستخدام إموارد التظيمية لتحقق الأهدف بفعالية وكفاءة. الإدارة الجيدة

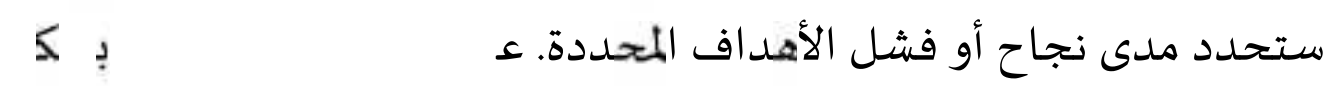

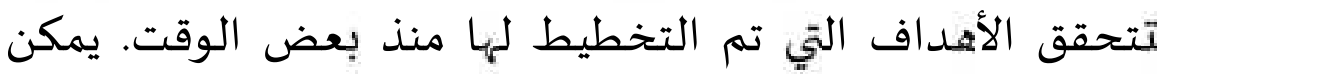
الاستتتاج من الإدارة هي سلسلة من الأنشطة التي توجد بها لهافيا عملية استخدام

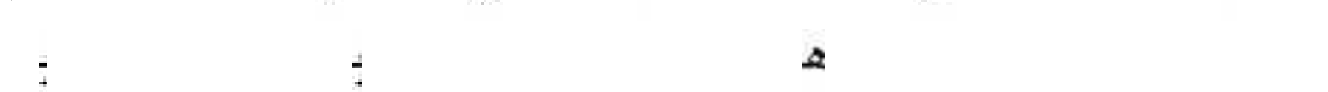
التخطيط والتنظيم والحركة والإشراف.

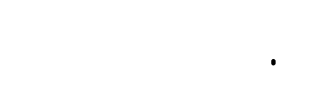

تشمل وظائف الإدارة في التعليم بشكل عامة يعني التخطيط والتظيم

$$
\text { والحركة والإشراف. البيلن هذه الوظائف كما التالي: }
$$

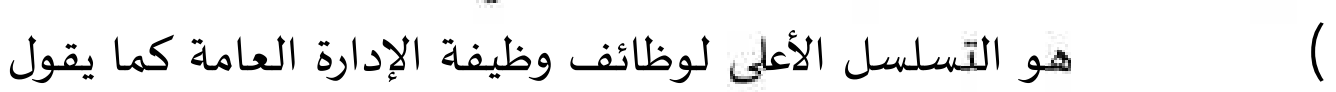

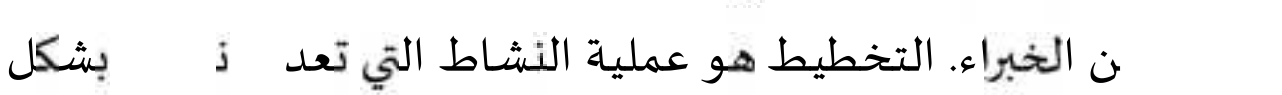

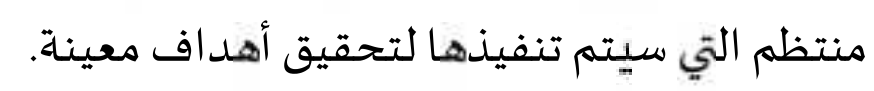

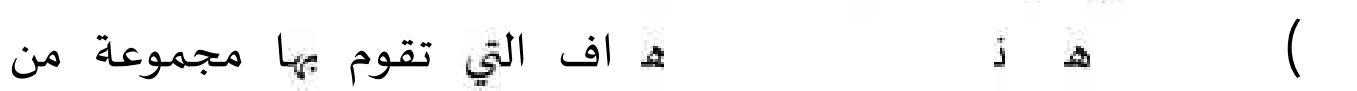
الأشخاص، والذي يتم تنفيذه عن طريف تقسيم لـهاهم وطسؤوليك

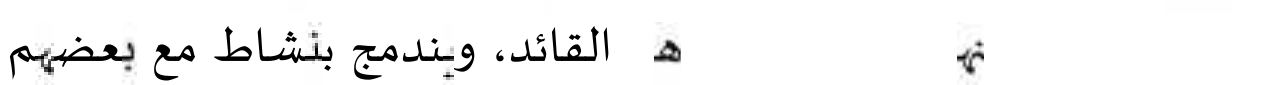
البعض. ج) الحركة، بمعنى التطبيق. وفقا ماجوني و ولدفسكي الحركة كتقويم. أما وفقا براون و ولدفسكي أن الحركة هي توسع في الأنشطة التي يتم تكييفها

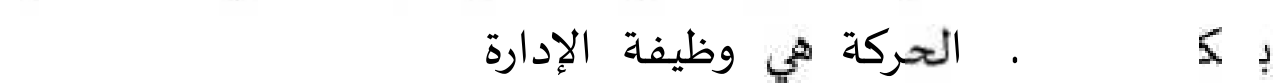

\footnotetext{
${ }^{1}$ Sufyarma, Kapita Selekta Manajemen Pendidikan, (Bandung: CV. Alfabeta, 2004), 188-189.

${ }^{2}$ Didin Kurniadin dan Imam Machali, Manajemen Pendidikan Konsep dan Prinsip Pengelolaan Pendidikan, (Jogjakarta: Ar-Ruzz Media, 2016), 126.

${ }^{3}$ Heidjarahman Ranupandojo, Dasar-Dasar Manajemen, (Yogyakarta: UPP AMP YKPN, 1996), 35.

${ }^{4}$ Nurdin Usman, Konteks Implementasi Berbasis Kurikulum, (Jakarta:PT. Raja Grafindo Persada, 2002), 70.
} 
والتظيم. الحركة هي جهد لتوجيه العمل واستخدام المرافق الموجودة التي تهدف إلى تنفيذ العمل معا. وظيفة هذه الحركة بمكانة مهيمة في تحقيق المجايق جميع الاهدف التظيمية.

د) الإثرل، هو الجزء الأخير من وظيفة الإدارة. تتضمن عملية الإشراف

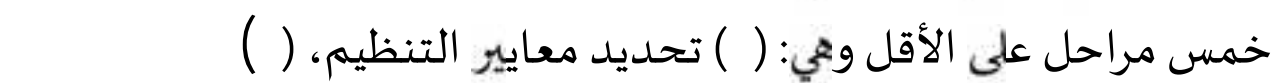

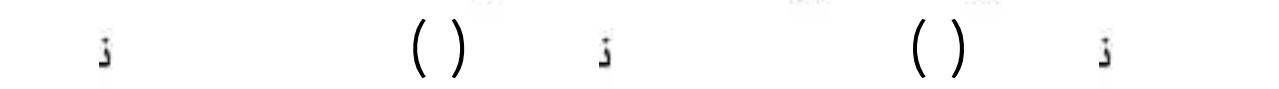

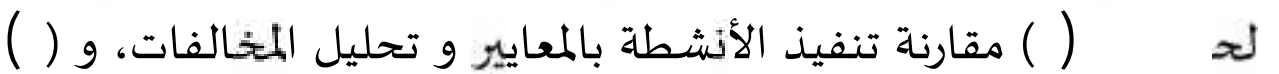

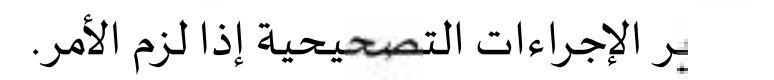

ب. برنامج لقسم تعليم اللغة العربية الكندي في الجامعة الإسلامية الحكومية

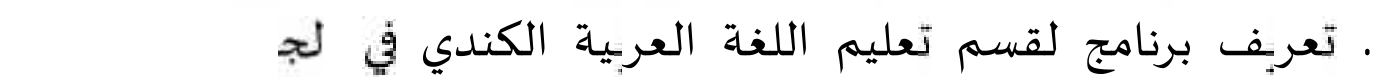
الحكومية

قال فارتنتو ودهلان أن البرنامج هو التخطيط المعين من السلطة أو الموان

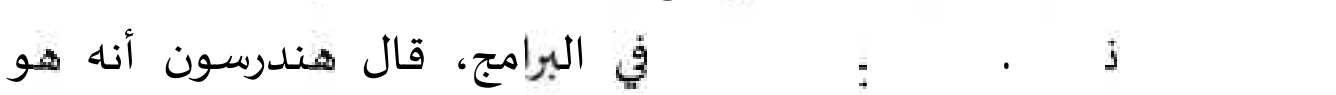

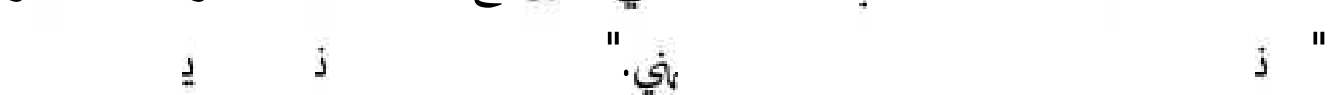

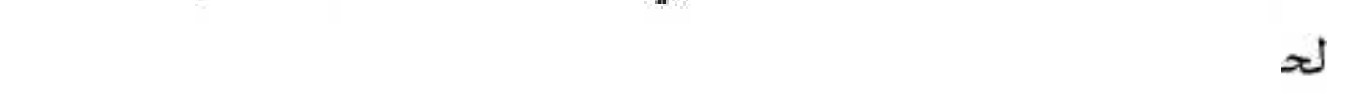

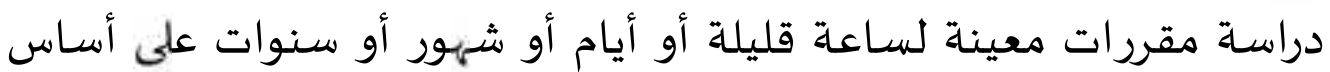
التفرغ الجزئ أو الكامل مع مجموعة من الزملاء.

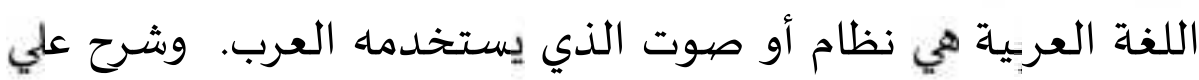

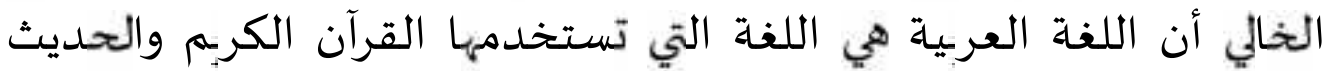

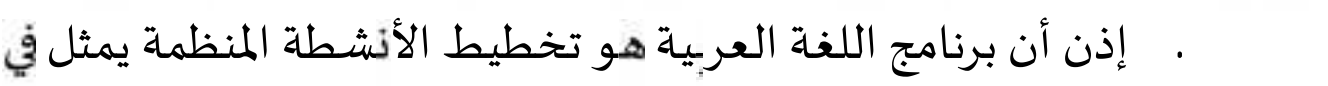

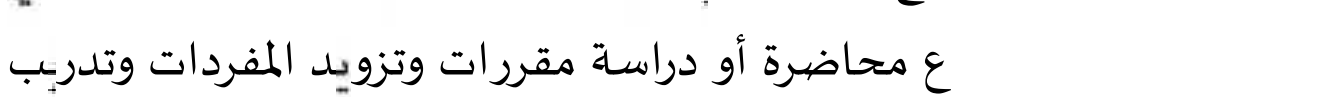

${ }^{5}$ Kurniadin, Manajemen Pendidikan 131.

${ }^{6}$ Prim Masrokan Mutohar, Manajemen Mutu Sekolah, (Yogyakarta:Ar-Ruzz Media, 2013), .40-42.

${ }^{7}$ Pius A Partanto dan M. Dahlan al-Barry, Kamus Ilmiah Populer, (Surabaya: Arkola, 1994), 628.

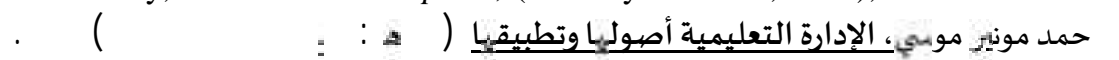

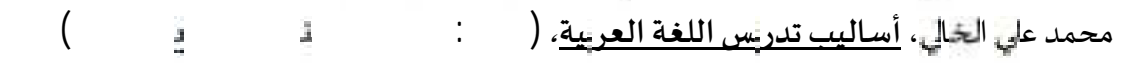
ا نفس المجع، 19. 
اللغنة الآخر يوميا كان أو شهربا أو سنويا الذي يتعلق بأصوات قوم العرب يعني اللغة العرةة. r. أنواع البرامج

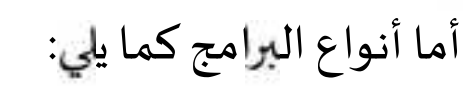

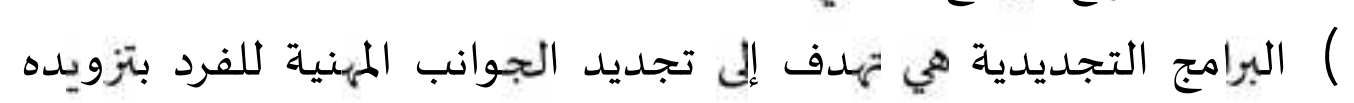

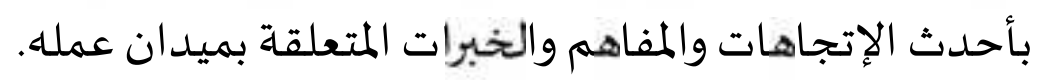

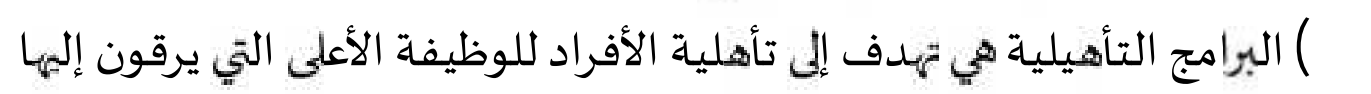
بعد تدربهه. وينبغي أن يقوم هذا النوع من البرامج الأسس التالية:شرح وتحليل الأسس القانونية والتشرعية التي تحكم العطل المقبل في علاقاته

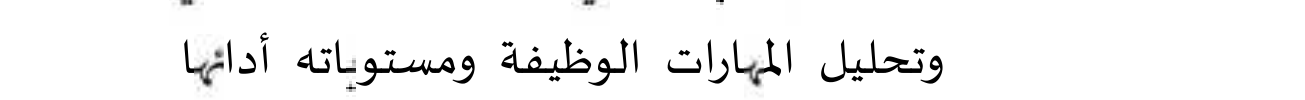
التدربب على تمثيل الدور.

ج. منهجية البحث أ. مدخل البحث ومنهجيته

المدخل الذي مستخدم في هذا البحث هو المدخل النوعي. أما نوع البحث في

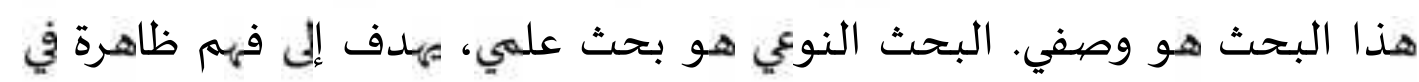

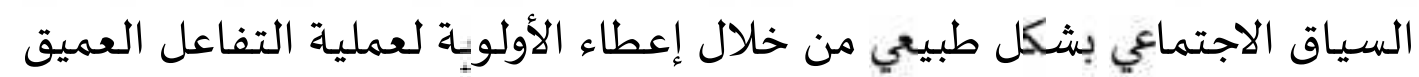

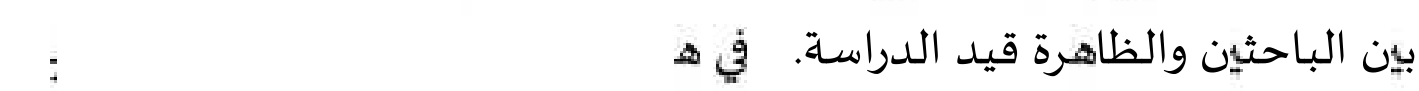

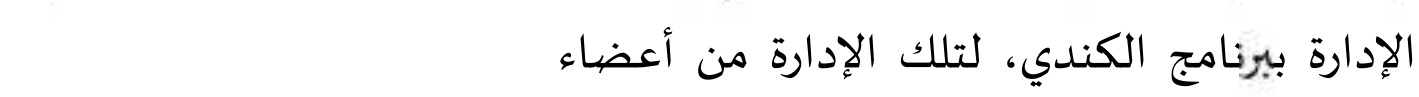

$$
\text { بمختلف المسابقلت. }
$$

إموضو في هذا البحث هو رئيس رالبطة الطلاب قي قسم تعليم اللغة

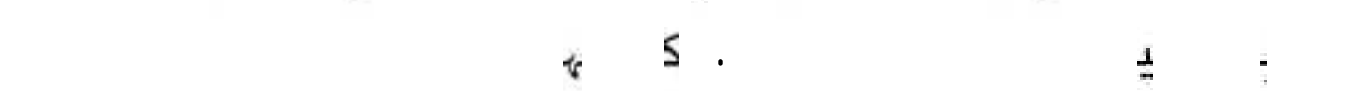
هو الحصول علىمعلوملت حول رابطة الطلاب وبرنامج الكندي. r. أدوات البهرث أ) طرقة جمع البيانت

.$|\Lambda \varepsilon-| \Lambda \mu$ " محمد مونير موسي، الإدارة التعليمية..

${ }^{12}$ Lexy J. Moleong, Metodologi Penelitian Kualitatif, (Bandung: Remaja Rosdakarya, 2002), 26. 
(1) اللالهظة، وتشمل الملاحظات نشاط تحميل من وجوه الانتباه إلى شيء

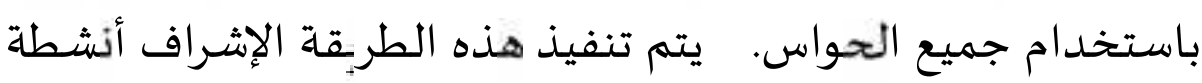
هيئة شباه المستقلة الكندي (BSO al-Kindy).

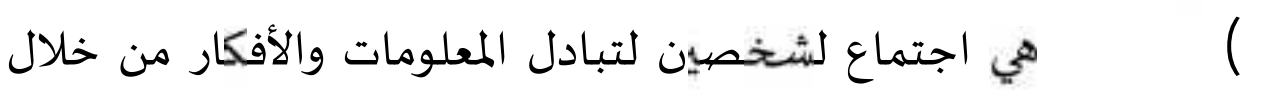

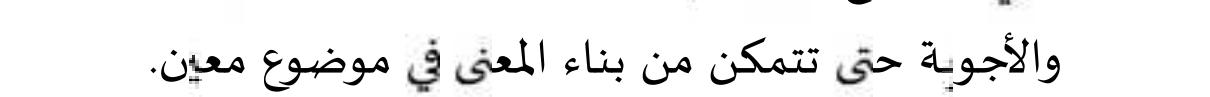
الباحثة مقابلة مع رئيس رابطة الطلاب في تعليم اللغة العربية ورئين هيئة شباه المستقلة الكندي.

") الوثلف، هو طربقة لجمع البيانات من خلال التراث المكتوب، وخاصية

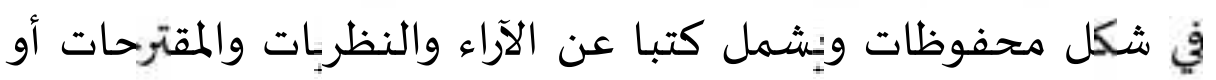
القوانين، إلخ. المتعلقة بمشكلة التحقيق.

في هذا البحث، فإن الوثائق المعنية هي وثائق البيانات ووثائق

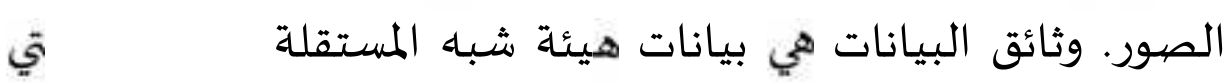
تشمل التاريخ الدائم، والمرافق والبنية التحتية، وكذلك هيكل فيكل الإدارة.

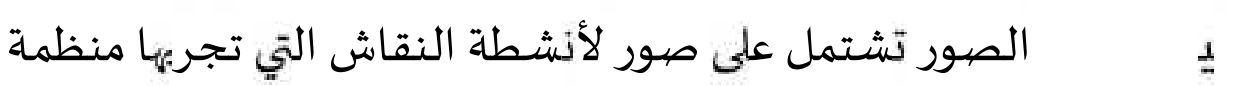
الكندي.

ع) التثليث، هومزبحمن تقنيت جمع البيانت المختلفة ومصادر البيانت

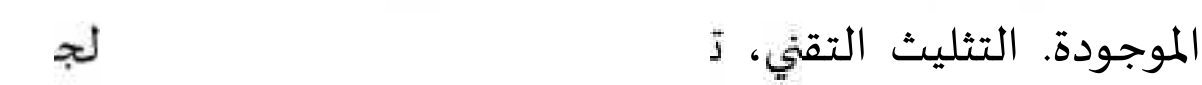

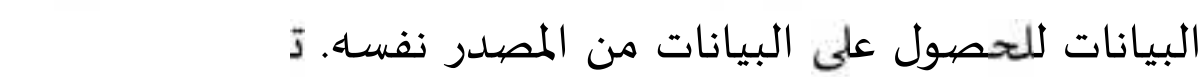

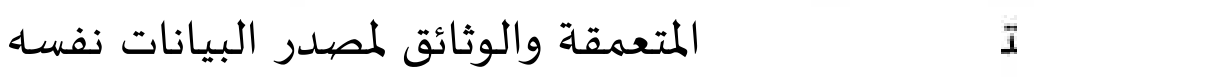
في وقت واحد. وبعني تثليث المصادر، للحصيول على بيانات من مصادر مختلفة بنفس التقنية. 17 س. أنواع البيانت ومصادرها أنواع ومصيادر البيانات في هذا البحث هو:

\footnotetext{
${ }^{13}$ Suharsimi Arikunto, Prosedur Penelitian Suatu Pendekatan Praktik, (Jakarta: Rineka Cipta,2006), 156. ${ }^{14}$ Sugiyono, Metode Penelitian Kuantitatif, Kualitatif dan R\&D, (Bandung: Alfabeta, 2017), 231.

${ }^{15}$ Mustofa Djaelani, Metode Penelitian bagi Pendidik, (Yogyakarta: PT.Multi Kreasi Satudelapan, 2010), 125-126.

${ }^{16}$ Sugiyono, Metode Penel 241.
} 
أ) البيانت الأسلسية. هي بيانت تم الحصول عليها مباشرة من الميدان، وعي البيانات التي تم جمعها من المستجيبين من خلال المقابلات البحثية المتعلقة بتنفيذ برنامج هيئة شبه المستقلة الكندي.

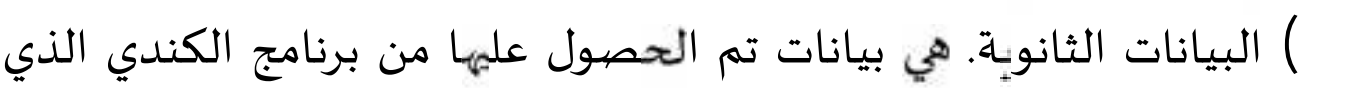

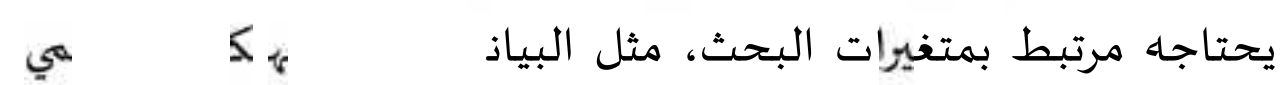

$$
\begin{aligned}
& \text { وكذالك الوثلف الطلوة وغيرها } \\
& \text { ع. تقنيت التحليل البيانت }
\end{aligned}
$$

تم إجراء تحليل للبيانات النوعية في هذا البحث بشكل استباقي، أي

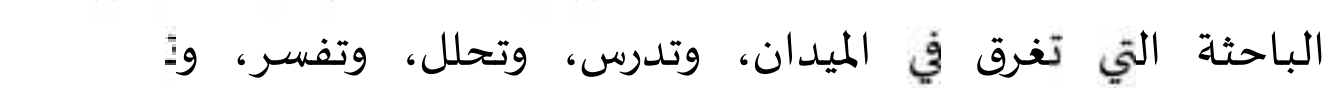

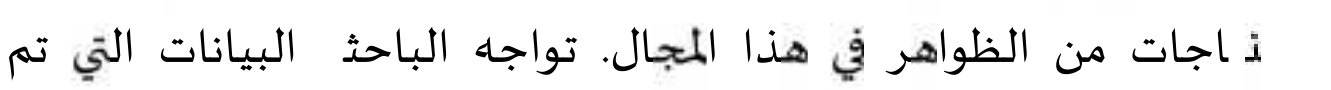
الحصول عليها من الميدان. من هذه البيانات، تجب على الباحثة أن تحلل

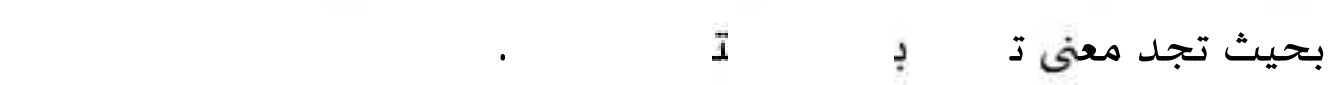

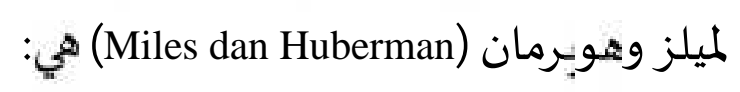

أ) تخفيض البيانت، يعني التلخيص واختيار الأشياء الرئيسية والتركيز على (لمانل

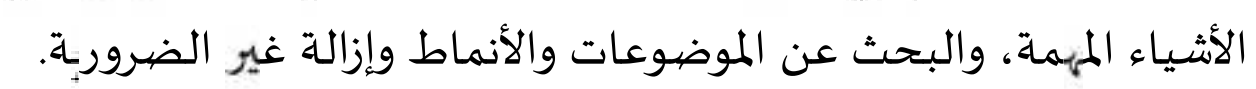
البيانات الخام التي تم الحصول عليها هي بيانات تتعلق بإدارة هيئة شبه

الهستقلة الكندي. ب) عوض البيانت، وفقا لمايلز وهوبرمان، فإن عرض البيانات عبارة عن

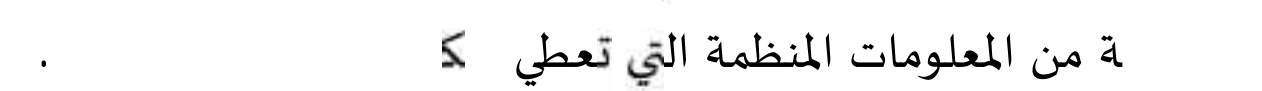

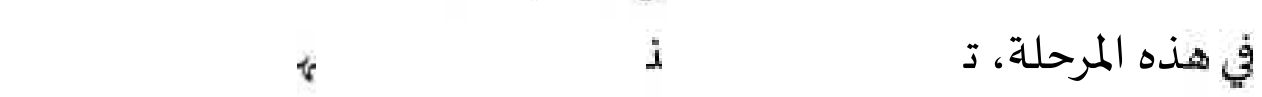

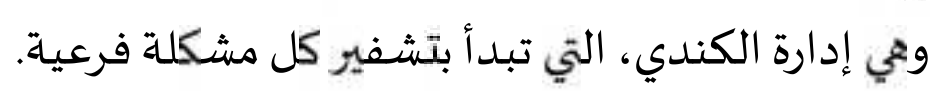

ج) الستنتاج أو التحقق، هو استخلاص استنتاجات تستند إلى النتائج

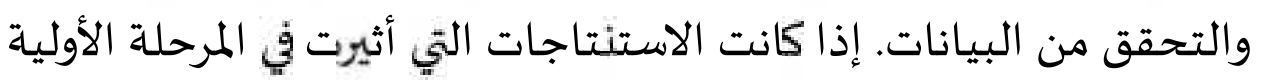

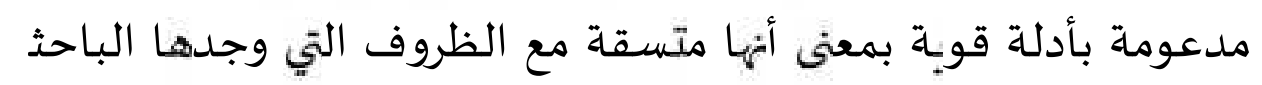

\footnotetext{
${ }^{17}$ Sugiyono, Metode Penelitian.............., 338.

${ }^{18}$ Muhammad Idrus, Metode Penelitian Ilmu Sosial Pendekatan Kualitatif dan Kuantitatif, (Jakarta :Erlangga, 2009), 151.
} 
عندما تعود إلى الميدان، فإن الاستنتاجات التي يتم الحصول عليها هي

لستنتاجلتموثوقة. 19

مع مرور الوقت، حققت هيئة شبه المستقلة الكندي العديد من الإنجازات التي

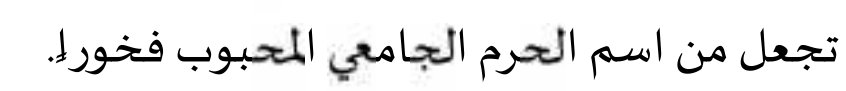

$$
\begin{aligned}
& \text { د. قائمة فائز من المستويات الوطنية }
\end{aligned}
$$

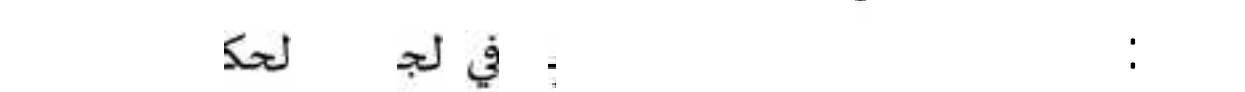

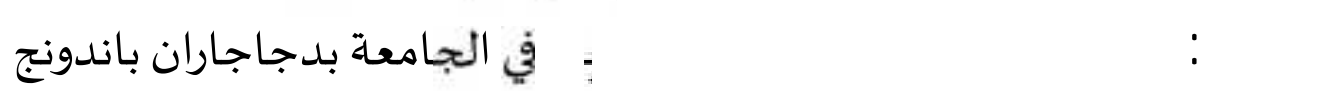

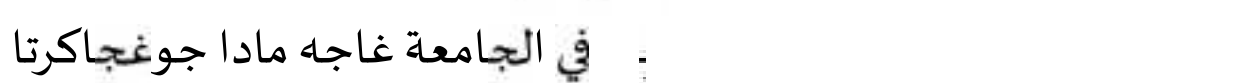

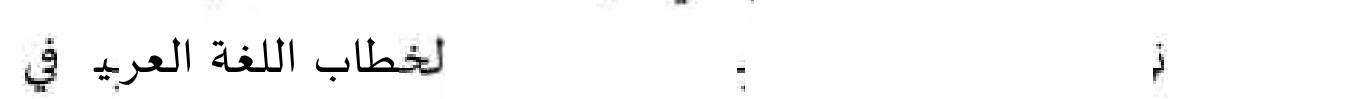

$$
\text { الجامعة الحكومية جاكرتا }
$$

الفائز الثانيطسابقة النقاث العرية في الجامعة الإسلامية الحكومية بانتين

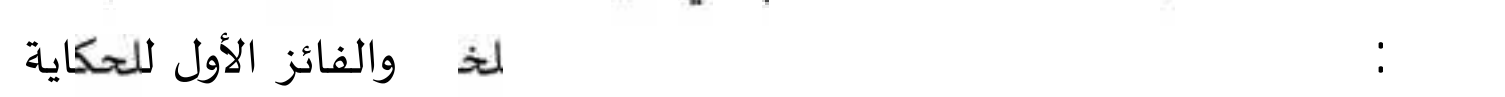

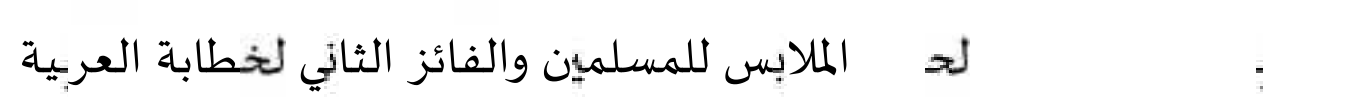

$$
\text { في الجامعة الإسلامية الحكومياة شربف هداية الله جاكرتا }
$$

عا ·r: الفائز العام العربية للفن في الجامعة الإسلامية الحكوية مولانامالك ابراهيم

$$
\text { مالانج، وغير ذاك. }
$$

من هذه انتصارات، بدأ قسم التعليم اللغة العرية وكلية التربية

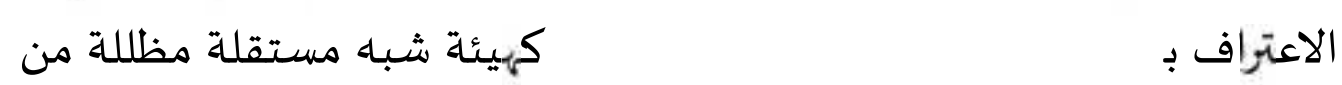

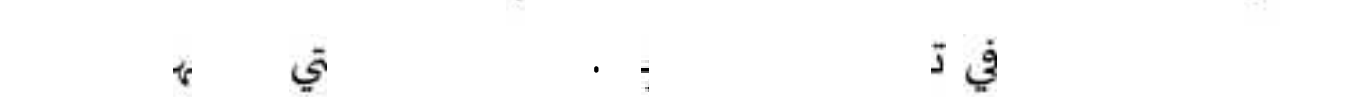

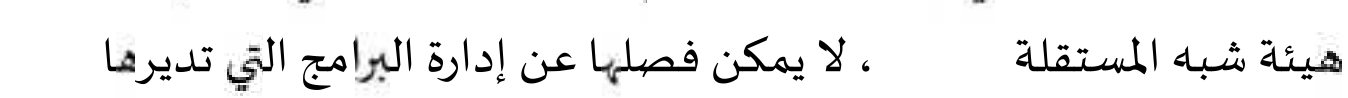

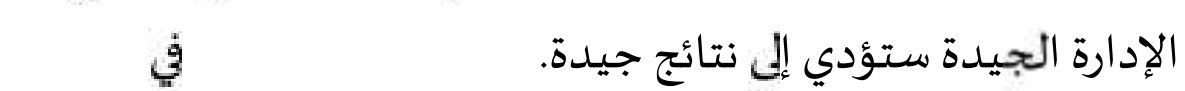

\footnotetext{
${ }^{19}$ Trianto, Pengantar Penelitian Pendidikan bagi Pengembangan Profesi Pendidikan dan Tenaga Kependidikan, (Jakarta: Kencana, 2011), 291.

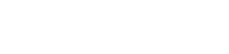

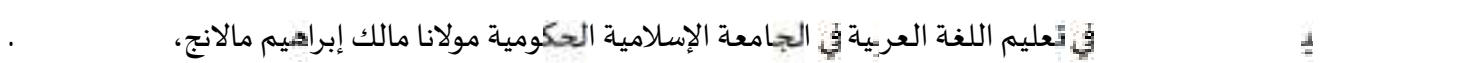




\section{أ) التخطيط}

في التخطيط، يجب على كل رئيس أن ينتبه إلى المستقبل، وبقول "هذا ما

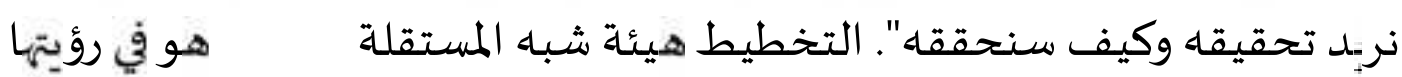
ورسالتها. - و تجها.

الرؤية: تطوبر وتحقيق أعضاك هيئة شبه المستقلة الكندي لديهم القدرة

$$
\text { على النقاش باستخدام اللغة العربية. }
$$

- - مغنس الحمال لأعضاك هيئة شبه المستقلة الكني للمشاركة في المسابقة. - مرافقة اعضاك هيئة شبه المستقلة الكني في تطوبر جودتها، خاصة في مهارة الكلام باللغة العرية.

- تشكل قيم التعاون والقرابة في هيئة شبه المستقلة الكندي. سيكون التخطيط الناضج في الهيئة مفيدا جدا في تحقيق الأهداف التئي تم تحديدها. يتم التخطيط عن طربق يصنع برنامج العطل:

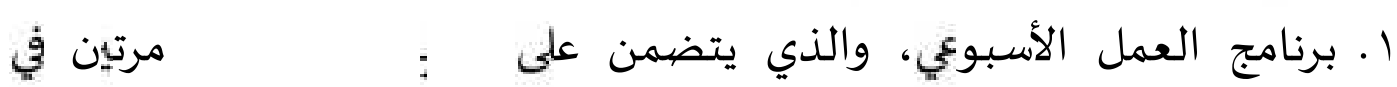
الأسبع، لي مساء الجمعة وصباح السبت. r. برنامج العطل السنوي، والذي يتضمن على نشاطين، وهما يوم إليلاد هيئة

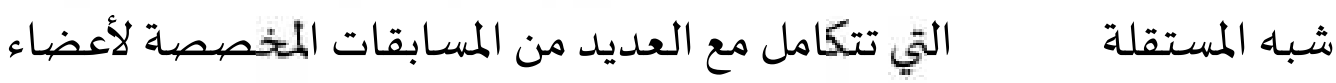

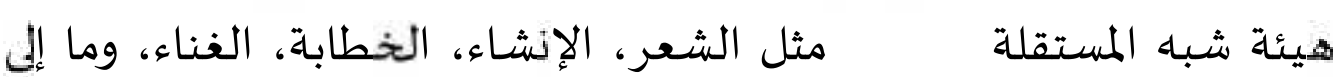
ذلك. والأنشطة في أوقات مختلفة هي انتخاب الرئيس الجديد لهيد لهيئة شبه الإنياء المستقلة الكندي.

يجب أن يكون كَ برنامج العطل بتقييم، بحيث يمكن تقييمه وتحسينه

$$
\text { إذا كان هناك شيء ناقس ويحتاج إلى تصحيح. }
$$

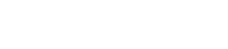

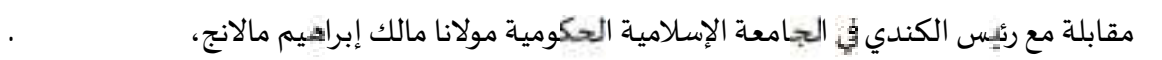


ب) تظيم

هو تجميع الأنشطة في أقسام أو عدة تقسيمات أخرى. في هيئة شبه

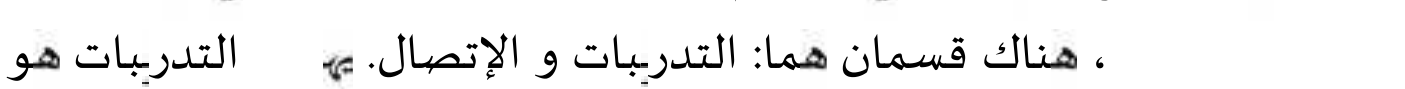

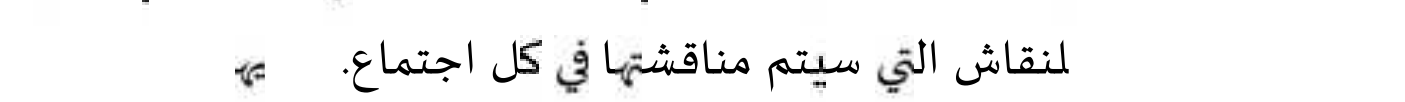
يعني ليبحثمعلومات حول المسابقة. ج) الحركة

المقصود يعنى تنفيذ الأنشطة الموجودة في هيئة شبه المستقلة الكني. هذه الأنشطة هي الشعر والتدرببات والخطابة وفن الخط والغناء وقراءة أخبار باللغة

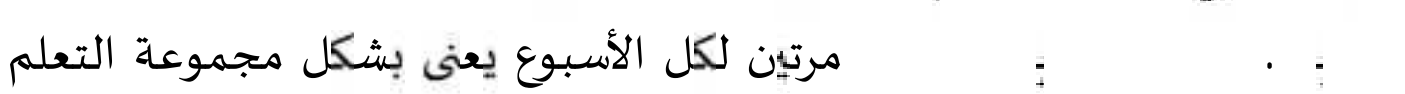

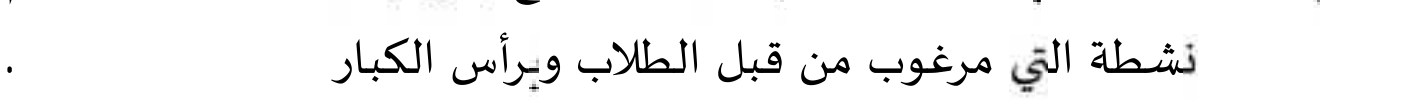

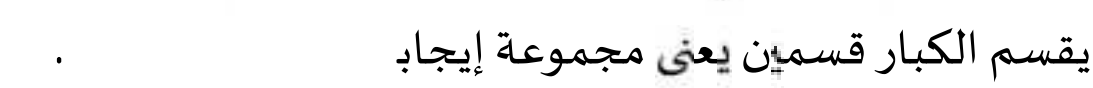
د) الإثرف الفيان

وظيفة من الإشراف يعنى تحديد التخطيط الأول لابد التصحيح أم لا يعنى

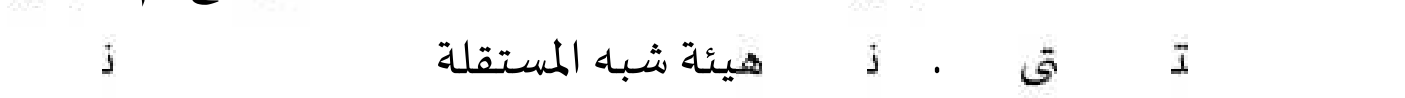

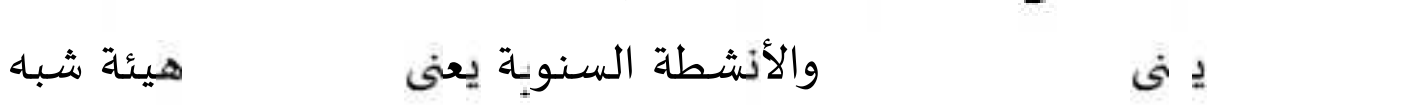

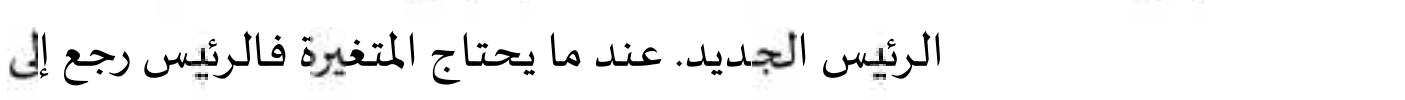

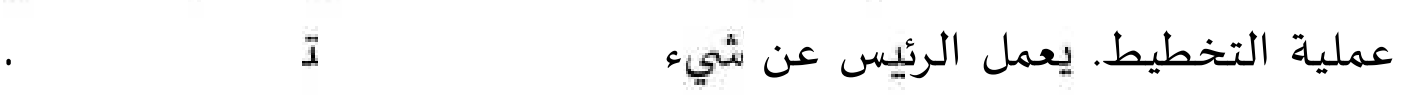

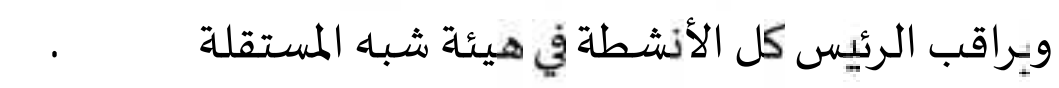

تحلل النوعي في هذا البحث يقوم بإستقرائي، يعنى لا يبدأ من الإستنتاج ظظرة ح. المناقشـة

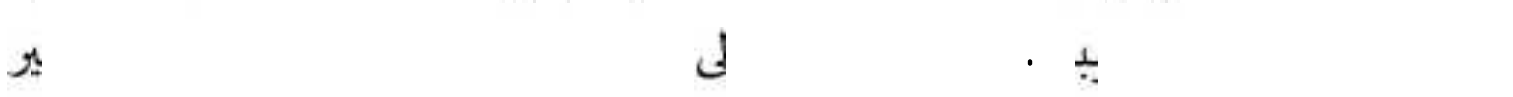

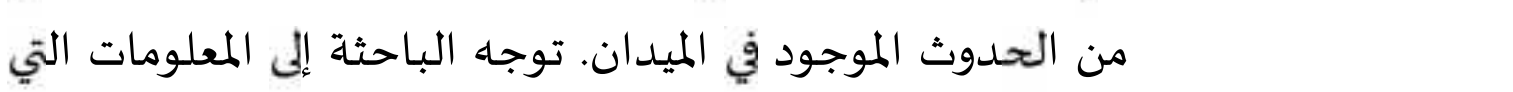

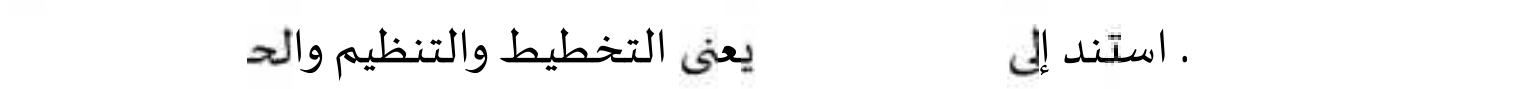

عَوثيقةمن رلطة الطلاب في تعليم اللغة العربية

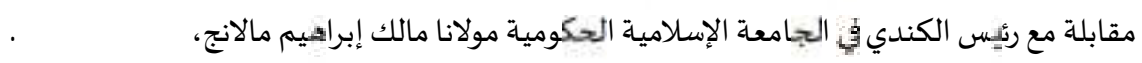

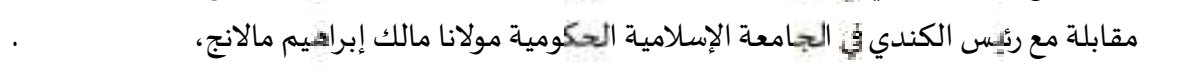


ستحلل الباحثة المعلومات التي وجدت من الملاحظة والمقابلة والوثيق. وظيفة الإدارة في الأنشظة تعلم اللغة الغربية في البرنامجلج هيئة شباء المستقلة المعات الكندي منها: أ. تخطط

تخطيط هو الأنشطة الأول التي يقوم في تنفيذ الإدارة وهو عملية ترتيب

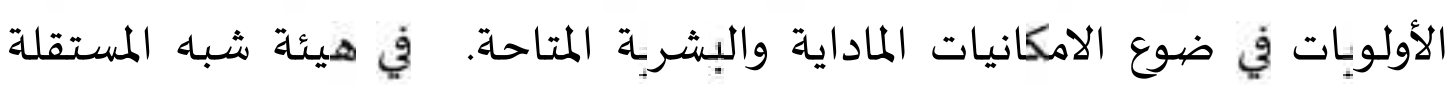
الكندي، الرئية والرسالة التي مخطط رئيسه بوسيلة غير مباشرة يدل على حلم هيئة شباء المستقلة الكندي في المستقل وخطوكت التي لابد تؤخذ. ثم عقد اجتماع برناميج العطل في كنى انتخاب الرئيس وفي ذلك اجتماع سيبحث عن إحتياجات لتحقيق

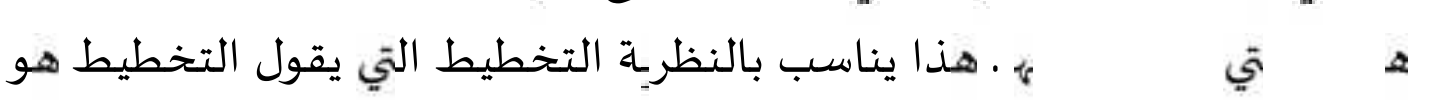

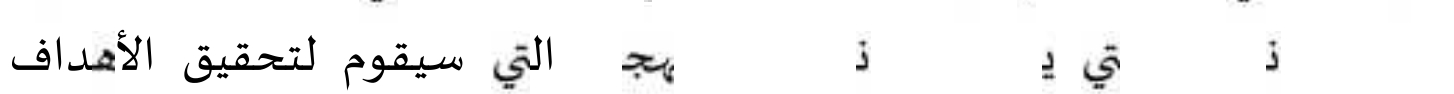

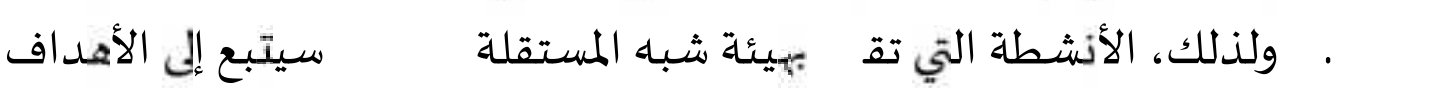

ولستعداد منهجي التي تخطيط قبلهيا. ب. التظيم

ترتيب بعض العناصر في مؤسسة التربوية هي الأنشطة الإدارة خاصة ويذكر بالتنظيم. التنظيم مهم في الإدارة لأن يصنع موقع الشخص ولَس واضع في هيكالية وعمله. ولذالك، يقوم التظيم بهيئة شبه المستقلة الكندي منلسب بتاك الظرة الإد لأن في هيئة شبـ المستقلة الكندي موجود قسمين يعنى قسم الإتصل وقسم التدربك. قسم

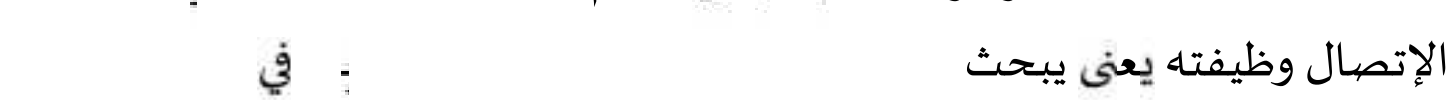

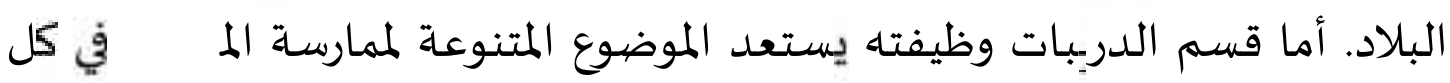

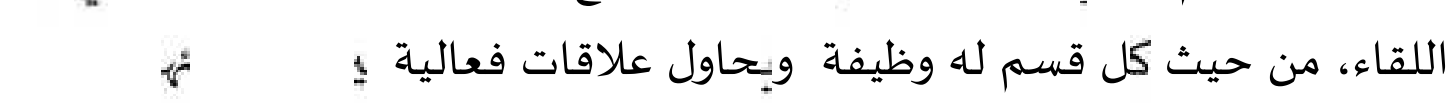

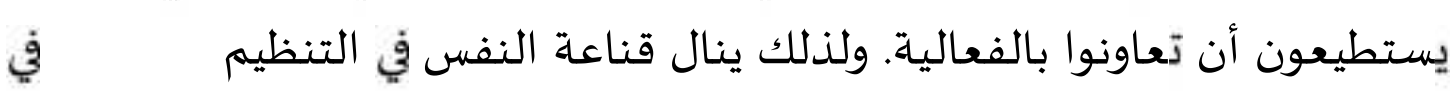
حالة البيئة معينة لتحقيق الأهداف.

${ }^{28}$ Kurniadin, Manajemen Pendidikan

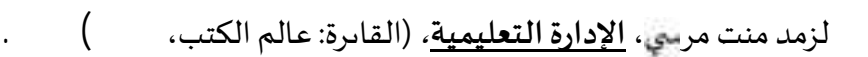
${ }^{29}$ Syamsuddin, Penerapan Fungsi-Fungsi Manajemen dalam Meningkatkan Mutu Pendidikan, Jurnal Idaarah, Vol. I, No. 1, Juni 2017,68. 


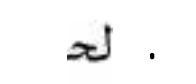

وفقا لبروني وويلدفسكي، الحركة هي التوسع في الأنشطة التي تتكيف مع بعضها

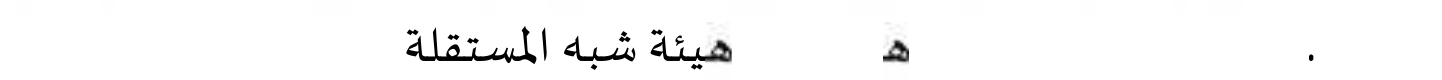

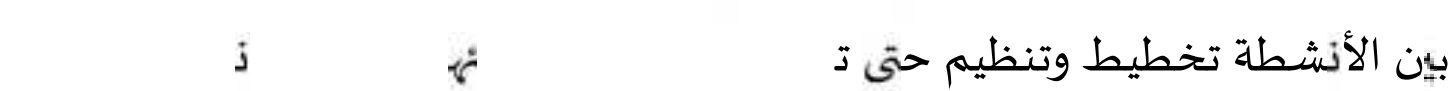

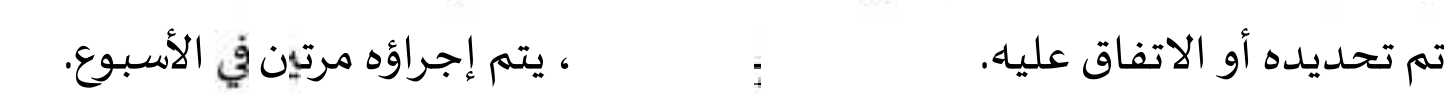

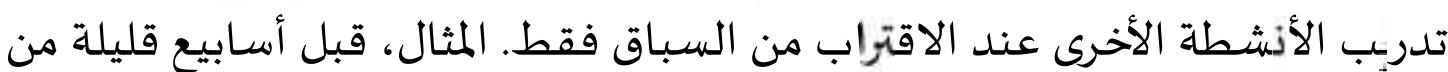

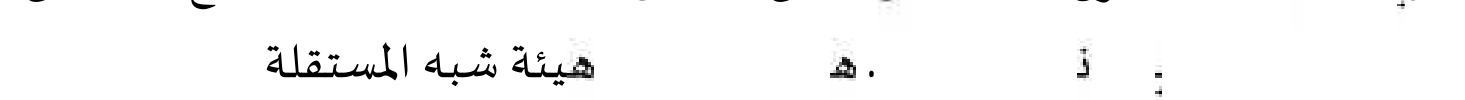
على المنظرة باللغة العرية. في كل التنظيم الأنشطة، سيعطي كبار من هيئة شباه المستقلة الكندي التوجيه والدوافح لتعلم. ستمكن هذه المجموعة الصلبة من القيام بالعديد من الأنشطة معا.

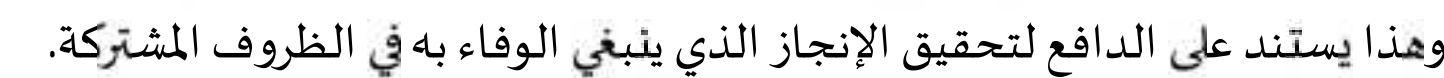

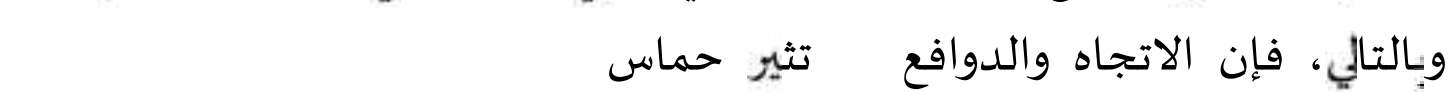
أحلامههم. د. الإشرف

\section{الوظيفة الثشرف في قياس مستوى الفعالية وستوى كفاءة لستخدامطرق}

وأدوات معينة عند بذل الجههود لتحقيق الأهداف التنظيمية بحيث يكون الإشراف في الواقع هو أداة قيلس لفعالية وكفاءة إذظمة. في هيئة شبه المستقلة الكندي، يتم

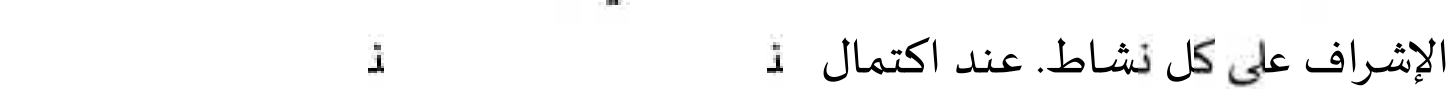

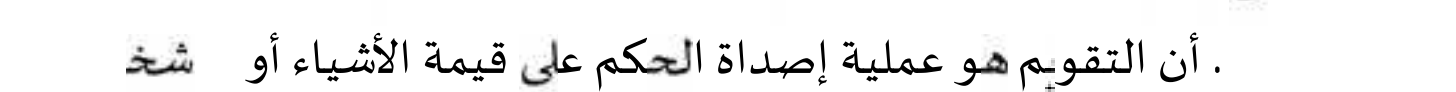

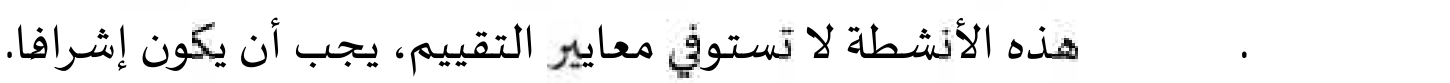
كما قال الدمرداش الإشراف بأنه يكون عونا على تحديد المشكلات وتشخيص الأخطاء ومعرفة العقبت لطعوقت لتحسن.

\footnotetext{
${ }^{30}$ Usman, Konteks implementasl ..............., 70.

${ }^{31}$ Rahmania Utari, Priadi Surya, dan Tina Rahmawati, Pembentukan Iklim Sekolah Dalam Perspektif Learning Community, Jurnal Manajemen Pendidikan Vol. 24, No. 1, Maret 2013, 24.

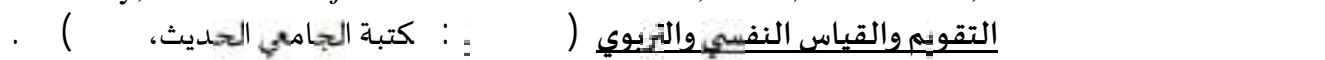

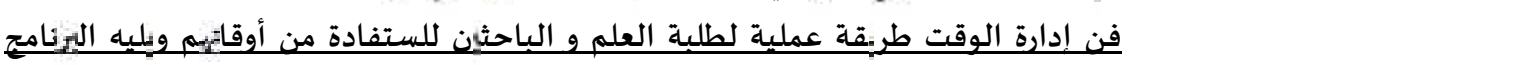

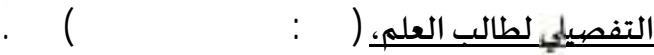


يقوم الإثرف من قلب رئيس مظمة هيئة شبه المستقلة الكندي تجاه أعضائها،

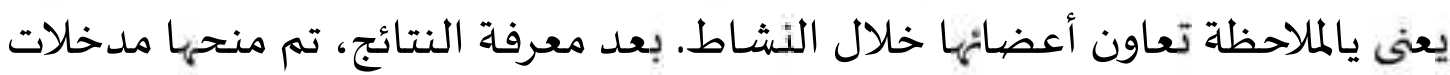

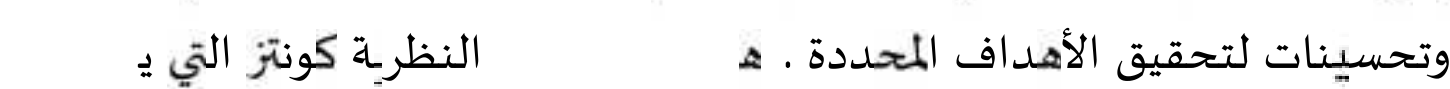

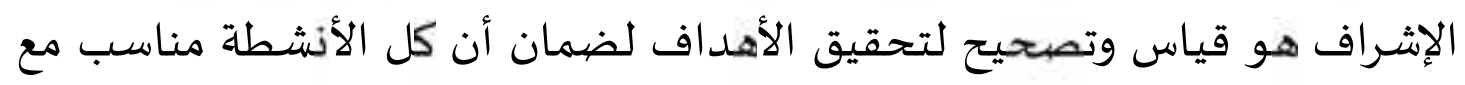
الخطة:" الخعر

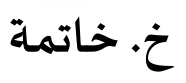
ا. ملخع نتائج البهث

هيئة شبه المستقلة الكندي يركز في النشاط المنظظرة من الأنثطة الأخرى مل الإنل

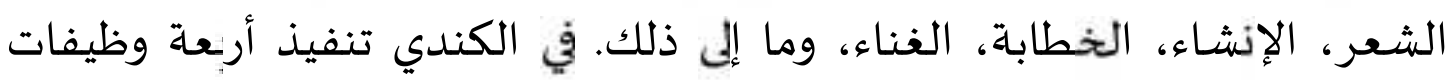

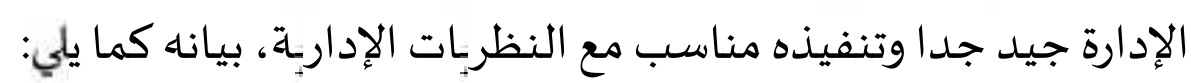

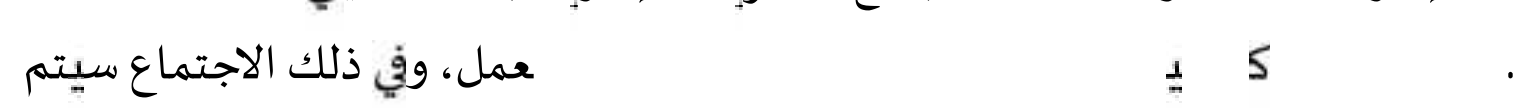

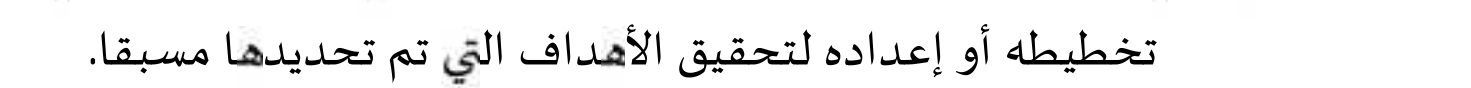

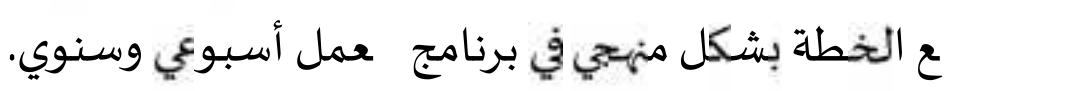

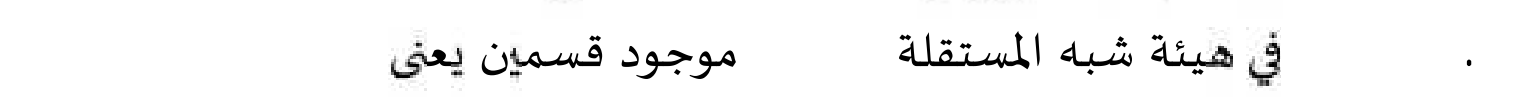

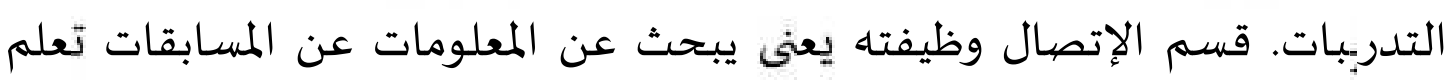

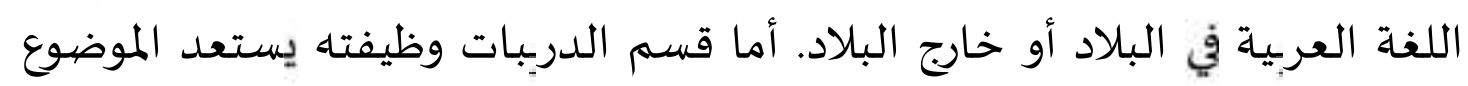

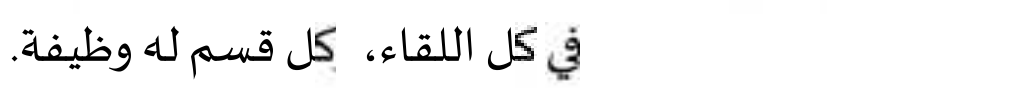

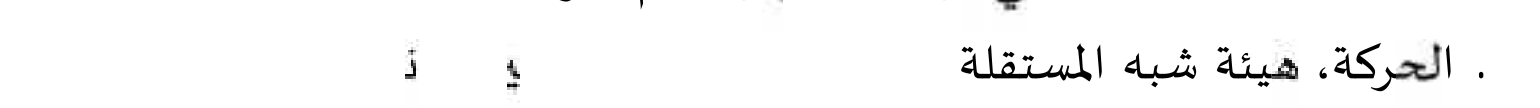

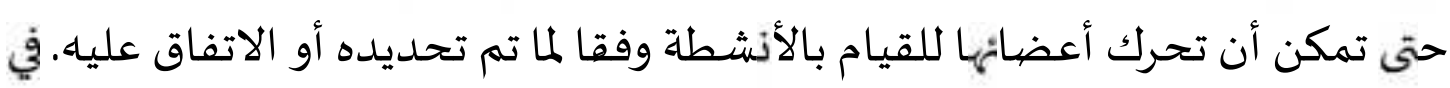

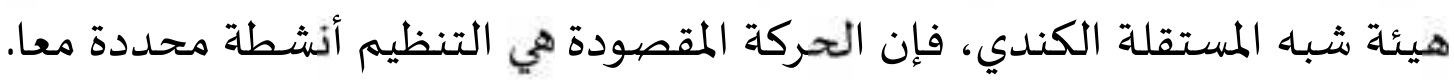

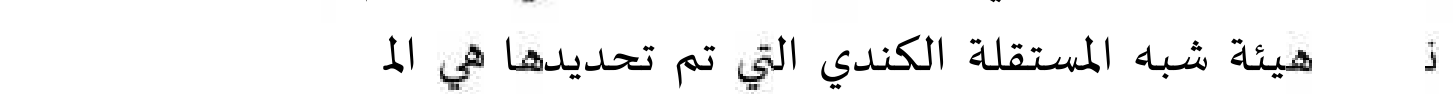
الكتب، إنثاء، خطابة، الخط، الغناء، وقراءة الأخبار العرية.

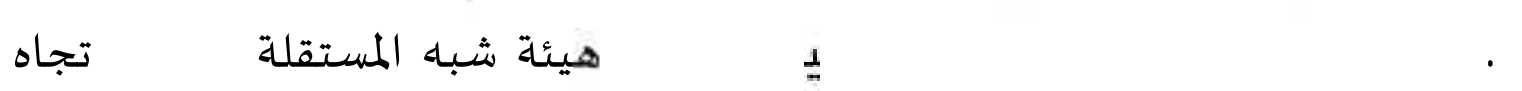

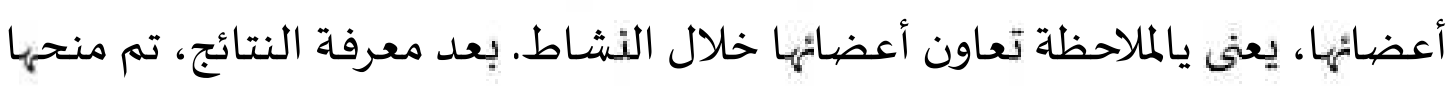

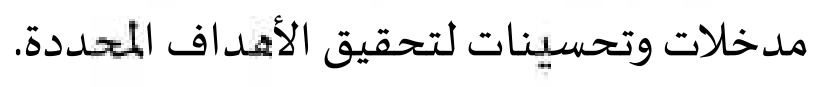

\footnotetext{
${ }^{34}$ Koontz, Manajement Function and Strategy, (Tokyo: Mc. Graw Hill Kogakusha, 1980), 65.
} 


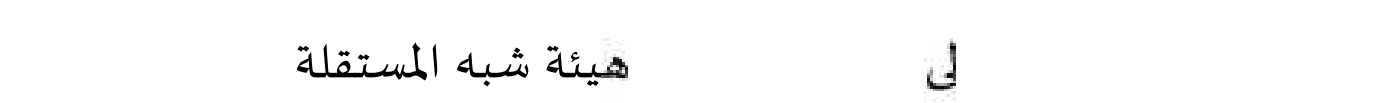

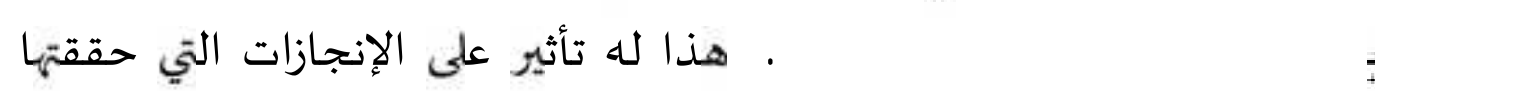

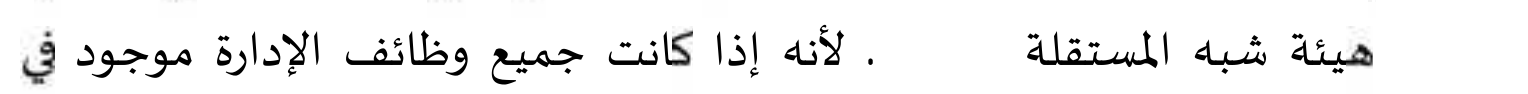

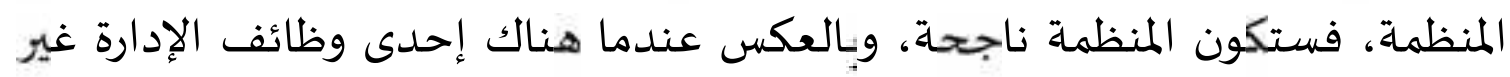
الموجودة في المنظمة، ستفشل المنظمة في إدارة منظمتها.

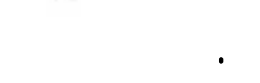
التوصيت من الباحثة: أ. من حيث التخطيط، الأفضل التخطيط لبرامج العمل التي يتم تكميلها يعنى بزبادة

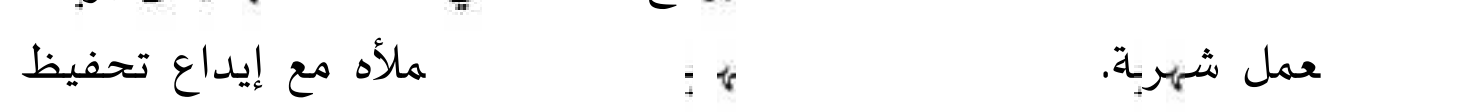
المفردات، وإيداع ملخصات لمدة شهر، وغير ذلئ ذلك.

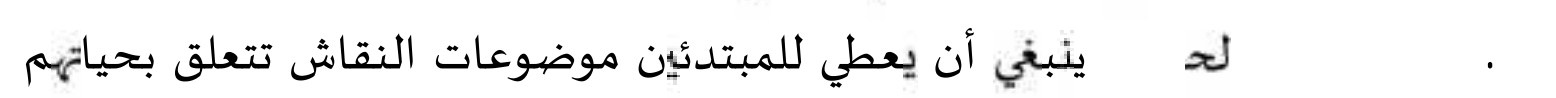
اليومية مل القمامة والظافة، وتأثير وسالل الإعلام الاجتماعية، ولستخدام

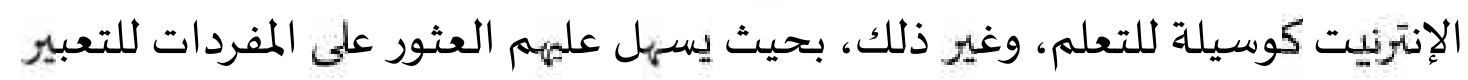

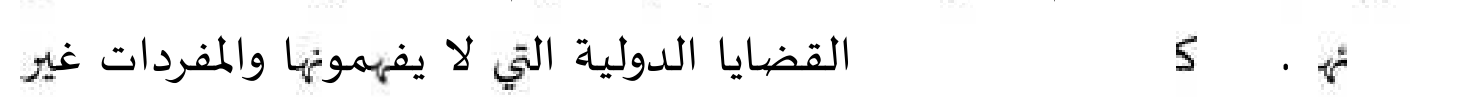
معروفة بالنسبة لهيم. 


\section{المراجع}

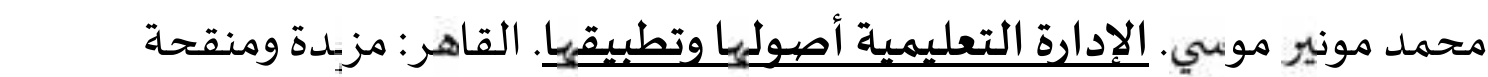

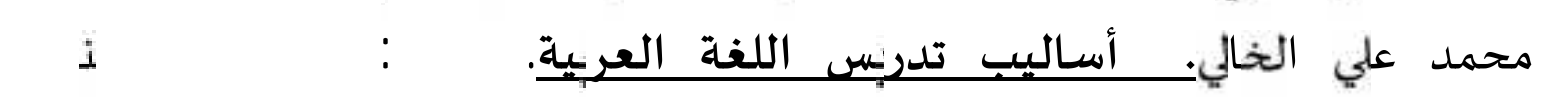

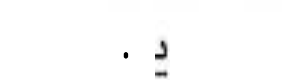

وليد كمل عفيفي القفه. التقويم والقياس النفيسي والتريوي. لإسكندرة: الهتبة

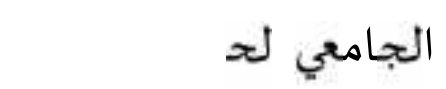

عبد \بن مبارك ل لسف. فن إدارة الوقت طريقة عملية لطلبة العلم و الباحثين

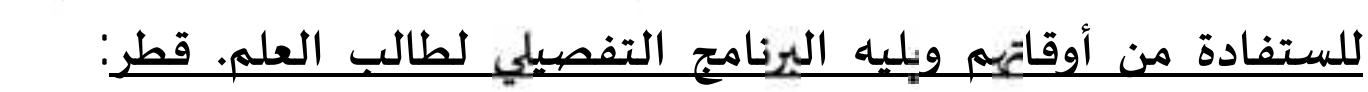

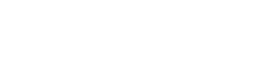

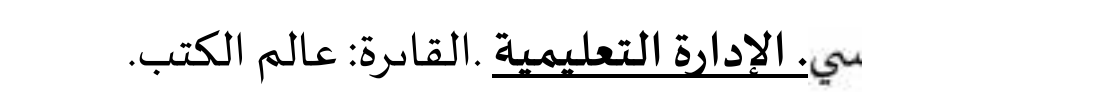

Suharsimi Arikunto, Prosedur Penelitian Suatu Pendekatan Praktik. Jakarta: Rineka Cipta, 2006.

Mustofa Djaelani, Metode Penelitian bagi Pendidik. Yogyakarta: PT.Multi Kreasi Satudelapan, 2010.

Muhammad Idrus, Metode Penelitian Ilmu Sosial Pendekatan Kualitatif dan Kuantitatif. Jakarta: Erlangga, 2009.

Koontz, Manajement Function and Strategy, Tokyo: Mc. Graw Hill Kogakusha, 1980.

Didin Kurniadin, dan Imam Machali. Manajemen Pendidikan Konsep dan Prinsip Pengelolaan Pendidikan, Jogjakarta: Ar-Ruzz Media, 2016.

Lexy J. Moleong, Metodologi Penelitian Kualitatif, Bandung: Remaja Rosdakarya, 2002. Prim Masrokan Mutohar, Manajemen Mutu Sekolah, Yogyakarta:Ar-Ruzz Media, 2013. Pius A Partanto, dan M. Dahlan al-Barry, Kamus Ilmiah Populer, Surabaya: Arkola, 1994. Heidjarahman Ranupandojo, Dasar-Dasar Manajemen, Yogyakarta: UPP AMP YKPN, 1996.

Sufyarma, Kapita Selekta Manajemen Pendidikan, Bandung: CV. Alfabeta, 2004.

Sugiyono, Metode Penelitian Kuantitatif, Kualitatif dan R\&D. Bandung: Alfabeta, 2017.

Trianto, Pengantar Penelitian Pendidikan bagi Pengembangan Profesi Pendidikan dan Tenaga Kependidikan. Jakarta: Kencana, 2011.

Nurdin Usman, Konteks Implementasi Berbasis Kurikulum, Jakarta:PT. Raja Grafindo Persada, 2002.

Syamsuddin. Penerapan Fungsi-Fungsi Manajemen dalam Meningkatkan Mutu Pendidikan. Jurnal Idaarah. Vol. I. No. 1. Juni 2017.

Rahmania Utari, dkk, Pembentukan Iklim Sekolah Dalam Perspektif Learning Community dalam Jurnal Manajemen Pendidikan ,Vol. 24. No. 1. Maret 2013. 